\title{
PREVENTION OF POST-ANAESTHESIA SHIVERING
}

\section{A. Eugene Pflug, Geordis M. Aasheim, Charlene Foster, and Roy W. Martin}

THE PURPOSE OF THIS STUDY was to investigate whether heat transfer by the lungs will prevent hypothermia during operation and whether post-anaesthesia shivering can be prevented if the patient is maintained normothermic in both the operating room and the recovery room. To achieve this, the lungs were ventilated with warm humidified anaesthetic gases during operation.

Shivering is a frequent post-anaesthetic complication. ${ }^{1.2}$ In the recovery room it may be associated with violent skeletal muscle activity resulting in increased oxygen consumption up to 500 per cent, increased cardiac work and decreased oxygenation of arterial blood ${ }^{3,4}$

Various methods have been used to prevent shivering including thermal blankets ${ }^{5}$ and heat exchangers. ${ }^{6}$ These forms of external heat or extracorporeal heat exchange are not always practical or effective. ${ }^{6.7}$

The lung may be the heat exchanger needed to prevent post-anaesthesia shivering consistently. Pulmonary heat transfer can take place over a large surface area which represents 50 to 75 square meters of alveolar epithelial-pulmonary capillary interface in the adult and a mucosa to bronchial blood interface in about one million small bronchioles. ${ }^{8}$ This air-tissue and tissueblood heat transfer takes place at the center of the body in an organ that surrounds the heart and the warmed blood then moves to the peripheral tissues through the vascular system.

\section{Methods}

Forty adult patients were studied. Each required inhalatioh anaesthesia for prolonged elective abdominal operations, had fasted for 12 hours and were not premedicated. Patients were selected for study only if they had no other

A. Eugene Pflug, M.D., Geordis M. Aasheim, M.D. Charlene Foster, R.N., M.N., and Roy W. Martin, Ph.D. Department of Anesthesiology and the Anesthesia Research Center, University of Washington School of Medicine, Seattle, Washington 98195 , U.S.A.

Reprints from : A. Eugene Pflug, M.D., Anesthesiology Service, Veterans Administration Hospital, 443 Beacon Avenue South, Seattle, Washington 98108 , U.S.A. known illness and were taking no regular medications. Informed consent was obtained from each patient before the study. Basic patient characteristics are listed in Table $I$.

The operations monitored were as follows: cholecystectomy - 11, exploratory laparotomy 5 , abdominal vascular (aortic-femoral graft, porto-caval shunts) -4 , colon -8 , and gastric 12.

All patients received general anaesthesia with induction by intravenous thiamylal $3 \mathrm{mg}$ to 8 $\mathrm{mg} / \mathrm{kg}$ with d'tubocurarine $5 \mathrm{mg}$, followed by succinylcholine $100 \mathrm{mg}$. After tracheal intubation, anaesthesia was maintained with halothane 0.5 to 1.5 per cent and nitrous oxide-oxygen 50:50. Pancuronium $0.05 \mathrm{mg} / \mathrm{kg}$ by intravenous injection was used to maintain muscle relaxation. Ventilation was controlled with a volumecontrolled anaesthesia ventilator, set to deliver a tidal volume of $15 \mathrm{ml} / \mathrm{kg}$ at a rate to maintain the $\mathrm{PaCO}_{2}$ at 30 to $40 \mathrm{~mm} \mathrm{Hg}$. Twenty of the $40 \mathrm{pa}$ tients, selected at random, were warmed during operation by using a modified Bennett Cascade Humidifier to warm the inspired anaesthetic gases. The temperature of the inspired gases was maintained at $42^{\circ}$ to $47^{\circ} \mathrm{C}$ at the $\mathrm{Y}$-connector of the anaesthesia tubing.

The humidifier was placed in the inspiratory circuit between the ventilator and the Y-connector (Figure 3). Standard $101 \mathrm{~cm}$ polyethylene anaesthetic circuit tubing was used for gas conduction and a Portex disposable tracheal tube with plastic connector completed the breathing system.

The gases were humidified as well as heated as they passed through the unit. The humidification is important as some of the heat transfer is due to heat loss of the vapour as it condenses to water. The original thermostat control used in the Cascade humidifier would not allow heating of the unit to $60^{\circ} \mathrm{C}$ the temperature needed to provide gases within a $42^{\circ} \mathrm{C}$ to $47^{\circ} \mathrm{C}$ range at the Y-connector, even though the 100-watt heating element in the humidifier had adequate heating capability. Therefore, a solid state switch (a triac RCA-40526) in conjunction with a triac controller (RCA CA3059) was used instead of the original 
TABLE I

Characteristics of Patients Studied (Means $\pm \mathrm{SD}, \pm$ SEM)

\begin{tabular}{|c|c|c|c|c|c|c|c|c|}
\hline & \multicolumn{2}{|c|}{ Age (years) } & \multicolumn{2}{|c|}{ Weight $(\mathrm{Kg})$} & \multicolumn{2}{|c|}{ Height (meters) } & \multicolumn{2}{|c|}{$\begin{array}{c}\text { Duration of } \\
\text { operation (hrs) }\end{array}$} \\
\hline & uwt & $w^{*}$ & uw & $w$ & uw & $w$ & uw & w \\
\hline $\begin{array}{l}\frac{\pi}{X} \\
S D \\
S E \\
P\end{array}$ & $\begin{array}{r}20 \\
50.5 \\
\pm 15.2 \\
\pm 3.5\end{array}$ & $\begin{array}{c}20 \\
55.2 \\
\pm 11.6 \\
\pm 2.7 \\
\mathrm{NS}\end{array}$ & $\begin{array}{r}20 \\
71.8 \\
+12.3 \\
\pm 2.8\end{array}$ & $\begin{array}{c}20 \\
77.5 \\
\pm 17.3 \\
\pm 4.0 \\
\mathrm{NS}\end{array}$ & $\begin{array}{r}19 \\
1.73 \\
+9.7 \\
\pm 2.3\end{array}$ & $\begin{aligned} & 20 \\
& 1.73 \\
& \pm 6.1 \\
& \pm 1.4 \\
& \text { NS }\end{aligned}$ & $\begin{array}{r}20 \\
4.2 \\
\pm 1.6 \\
0 \pm .4\end{array}$ & $\begin{array}{l}20 \\
4.0 \\
\pm 1.4 \\
\pm 0.3 \\
\text { NS }\end{array}$ \\
\hline
\end{tabular}

$* w=$ warmed.

fuw = unwarmed.

NS $=$ no statistical difference between $w$ and uw groups.

element. A thermistor was located inside a tube that projected below the water level in the humidifier. This thermistor provided the temperature sensing feedback for the control circuit. A potentiometer calibrated, labelled, and located at the top of the unit provided an adjustable control for setting the temperature. The modified circuit fitted into the same housing as the original thermostat. After modification the humidifier had the same external appearance, except for ventilation holes which were added to the housing to assist in dissipating heat generated in the circuit. The cleaning, sterilizing, and general use of the humidifier remained unaltered.

In the operating room all patients were draped with the same material except for the addition of a common cotton blanket over the arms and legs of the patients receiving warmed gases.

In the recovery room all patients received the same care except that the patients who had received warm gases during operation were covered with one additional common cotton blanket and inhaled warm humidified oxygen from a standard heated Puritan humidifier. The oxygen from the Puritan humidifier was not heated for the control patients. Room temperature was monitored with a mercury thermometer. * Body core temperature was recorded from tympanic and oesophageal thermistor probes (Surg-a-temp, Arlbrook Inc., Arlington, Texas), and skin temperature of the big toe and gas temperatures by Yellow Springs Instrument Co. probes. All these devices were calibrated in a water bath against a mercury thermometer* with a $20^{\circ}$ to $110^{\circ} \mathrm{C}$ range. The thermistor on the great toe was placed on the plantar surface, covered with a folded $4 \times 4$-inch

*Mercury filled, $20^{\circ}-110^{\circ} \mathrm{C}$ scale, full immersion, 12 -inch thermometer. Van Waters \& Rogers, Seattle, Washington 98134 , U.S.A. gauze pad and attached securely with cloth tape. Temperature of the inspired gases at the Y-connector was lowered by manual control of the resistor in the heating element of the humidifier whenever the patient's core temperature rose to $38^{\circ} \mathrm{C}$.

The following temperatures were monitored and recorded in all cases: temperature of gases three inches proximal to the inspiratory end of the Y-connector, gases in the humidifier and room air, tympanic, oesophageal and skin of the big toe. Each was monitored just before induction, after 15 to 20 minutes of inhalation anaesthesia without surgical stimulation, after the operation had progressed for one hour, when the peritoneal incision was being closed, 30 minutes after the patient had been admitted to the recovery room (early recovery), and after the patient had been in the recovery room for two hours (late recovery). The electrocardiogram was monitored by cardioscope throughout the study.

Arterial blood gas values were obtained if and when the patient shivered. Blood was drawn from an in-dwelling radial artery catheter while the patient was breathing room air. Analysis of the arterial blood gases were done on Instrumentation Laboratories 113 blood gas analyzer. with appropriate corrections being made for core temperature.

For purposes of this study, shivering was defined as post-anaesthesia muscular hyperactivity occurring after the patient was responding to simple commands and was aware of his surroundings. The patient commonly complained of feeling cold and said he was shivering and showed pilo-erection. Spastic muscle hyperactivity which occurred before regaining consciousness was not called shivering. Statistical significance was determined by t-test for paired observations. 


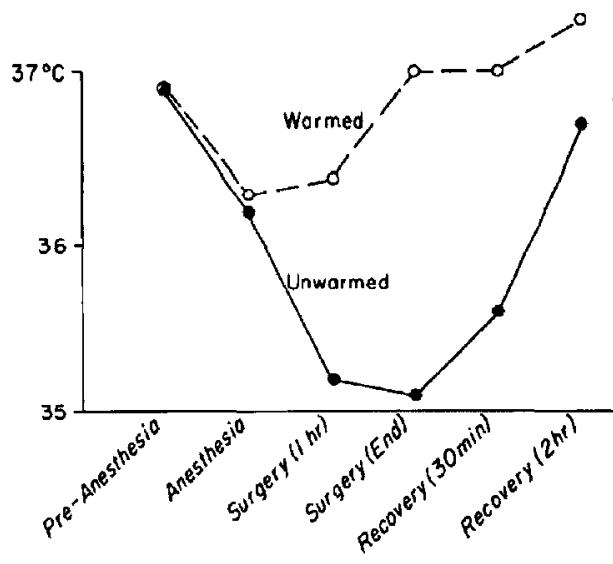

Figure 1. Mean tympanic temperatures of 20 patients warmed by ventilation with heated humidified anaesthetic gases and 20 unwarmed patients at various times during prolonged abdominal operations and during recovery.

\section{RESULTS}

Comparable mean values were found for age, weight, height and duration of operation ( $p=$ n.s.) for those patients receiving warmed gases during their operation and those who did not (Table I). Throughout these studies the operating room temperature was uniformly maintained at $22^{\circ}$ to $23^{\circ} \mathrm{C}$ as was the post-anaesthesia recovery unit $\left(23^{\circ}\right.$ to $\left.24^{\circ} \mathrm{C}\right)$. Pre-anaesthesia control measurements showed a marked similarity between the warmed (w) and unwarmed (u) group for mean toe and tympanic temperatures (Figures 1 and 2, Table V), (toe $u=27.5^{\circ} \mathrm{C}$ and $w=27.5^{\circ} \mathrm{C}$, tympanic $\mathrm{u}=36.9^{\circ} \mathrm{C}$ and $\mathrm{w}=36.9^{\circ} \mathrm{C}$ ).

Inhalation anaesthesia maintained for 15 to 20 minutes without surgical stimulation resulted in a consistent decrease in tympanic (Figure 1) and a consistent increase in toe skin temperature (Figure 2) when compared to control values (mean change $(\Delta)$ Toe $u=+3.6^{\circ} \mathrm{C}$ and $w=+5.2^{\circ} \mathrm{C}$ mean $\Delta$ tympanic $\mathrm{u}=-0.7^{\circ} \mathrm{C}$ and $\mathrm{w}=-0.6^{\circ} \mathrm{C}$ ). A statistically significant difference between values for the warmed and unwarmed groups was not found at this stage of the study.

Observations during prolonged anaesthesia and operation showed a decrease in toe, tympanic and oesophageal mean temperature values for all unwarmed patients when compared to similar values during anaesthesia alone (Tables II and V). (Toe $\Delta u=-0.5^{\circ} \mathrm{C}$, tympanic $\Delta u=-1.1^{\circ}$ $\mathrm{C}$, and oesophageal $\Delta \mathrm{u}=-1.0^{\circ} \mathrm{C}$. However,

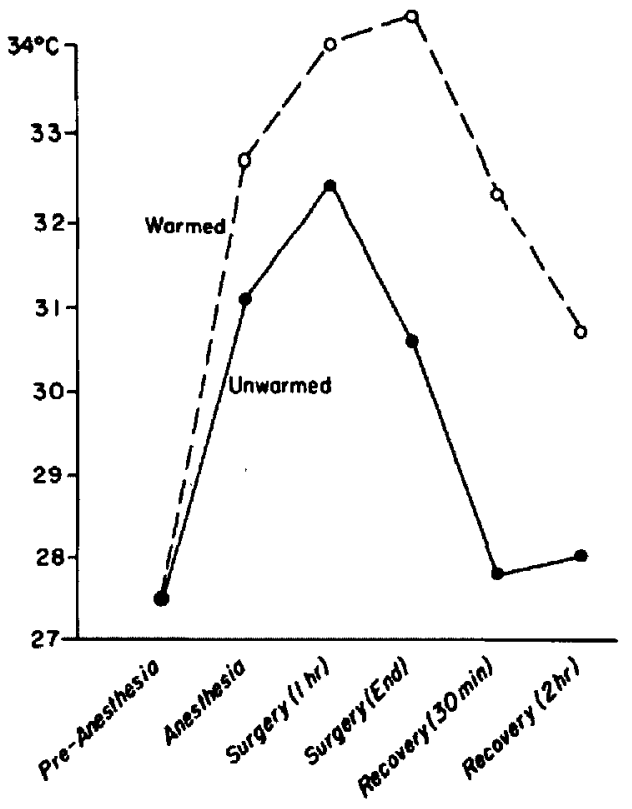

Figure 2, Mean temperatures of the skin of the great toe of 20 patients warmed by ventilation with heated humidified anaesthetic gases and 20 unwarmed patients at various times during prolonged abdominal operation and during recovery.

during the same time period the mean values for the warmed patients all increased (Figures 1 and 2, Tables III and V) (Toe $\Delta w=+1.6^{\circ} \mathrm{C}$, tympanic $\Delta w=+0.7^{\circ} \mathrm{C}$ and oesophageal $\Delta w=+1.1^{\circ}$ C). This represents a statistically significant difference between the unwarmed and warmed groups ( $p<0.0001$ ) (Table V).

Shivering in the recovery room was seen in 10 of 20 patients who were not warmed during anaesthesia (Table II). The mean duration of shivering was 0.48 hour ( 29 minutes) ( $S D \pm 0.14$, $S E M \pm 0.04)$. The patients who shivered complained of being cold and extremely uncomfortable while appearing generally vasoconstricted and showing pilo-erection. One patient developed bradycardia with nodal rhythm while shivering. Arterial blood gases collected during shivering showed a $\mathrm{PaCO}_{2}$ in the range 50 to $60 \mathrm{~mm}$ $\mathrm{Hg}$ for three of ten patients and one was severely hypoxic $\left(\mathrm{PaCO}_{3} 26 \mathrm{~mm} \mathrm{Hg}\right)$ for a short period. All patients who shivered responded within 15 to 30 minutes to heating with warmed blankets and warmed humidified oxygen.

None of the 20 patients who had been warmed 
TABLE II

Temperatures $\left({ }^{\circ} \mathrm{C}\right)$ of the 20 Unwarmed Patients Before Anaesthesia (PA), During Anaesthesia (A), Late During Operation (LS), and Early During Recovery (ER) (Means $\pm S D, \pm S E M$ )

\begin{tabular}{|c|c|c|c|c|c|c|c|c|c|c|}
\hline \multirow[b]{2}{*}{ Pt.\# } & \multicolumn{4}{|c|}{ Tympanic } & \multicolumn{2}{|c|}{ Oesophageal } & \multicolumn{4}{|c|}{ Toe } \\
\hline & PA & $A^{*}$ & LS & ER† & A & LS & $\mathbf{P A}$ & A & LS & ER \\
\hline 1 & 36.8 & 35.5 & 34.9 & 35.2 & 34.9 & - & 24.2 & 27.6 & 25 & 24.4 \\
\hline $2^{5}$ & 36.9 & 36.4 & 35.3 & 36.5 & 36.5 & 34.5 & 25 & 28.5 & 30.7 & 28.2 \\
\hline $3^{5}$ & 36.7 & 35.6 & 35 & 35.2 & 35.4 & - & 26.4 & 33.4 & 29.6 & 27 \\
\hline $4^{5}$ & 37 & 36.9 & 35.4 & 35.9 & 36 & 35.1 & 22.6 & 22.3 & 22.9 & 25.4 \\
\hline $5^{5}$ & 37.1 & 37 & 35.6 & 36.2 & 35.2 & 35.6 & 23.3 & 24 & 32.5 & 28.8 \\
\hline 6 & 37 & 36 & 36 & 36.4 & 36 & 35.9 & 30.6 & 34.5 & 32.2 & 29.9 \\
\hline $7^{5}$ & 37.5 & 37.3 & 34.9 & 36.4 & 37.2 & 34.9 & 26.6 & 31.1 & 32.6 & 27.3 \\
\hline 8 & 36.4 & 36.4 & 35 & 35.4 & 36 & 33.7 & 28.2 & 33.3 & 34 & 30 \\
\hline 9 & 36.9 & 36.3 & 35.6 & - & 36.3 & 35.6 & 30.7 & 33.2 & 33.5 & - \\
\hline $10^{3}$ & 37 & 36.3 & 36.2 & 37 & 36.1 & 36 & 23.9 & 32.3 & 27.8 & 25.9 \\
\hline 11 & 36.6 & 36 & 34.6 & 35.2 & 35.7 & 34.4 & 28.6 & 33.5 & 31.8 & 28.2 \\
\hline 12 & 37.2 & 36.6 & 35.9 & 一 & 36.5 & 36 & 25.6 & 30.5 & 34.9 & - \\
\hline 13 & 37 & 36.4 & 34.8 & 35.4 & 36.2 & 35 & 27.2 & 32.5 & 32 & 27 \\
\hline 14 & 36.7 & 35.6 & 34.5 & 33.9 & 35.4 & 34.2 & 31.6 & 34.5 & 26 & 24.7 \\
\hline 15 & 36.8 & 36 & 35.7 & 36.1 & 36.2 & 36.1 & 31.1 & 35.1 & 35 & 30.8 \\
\hline $16^{5}$ & 36.5 & 35.3 & 33.6 & 33.9 & 35 & 33.4 & 28.4 & 29.2 & 29.5 & 28 \\
\hline $17^{s}$ & 36.8 & 35.8 & 35.3 & 35.6 & 35.5 & 34.5 & 29 & 34.2 & 28.7 & 27.5 \\
\hline $18^{5}$ & 36.8 & 35.5 & 35 & 36.4 & 35.1 & 34.6 & 28 & 33 & 33.6 & 30.8 \\
\hline 19 & 37.2 & 36.5 & 34.3 & 34.5 & 36.6 & 34.7 & 26.8 & 25 & 28 & 25.8 \\
\hline $20^{5}$ & 36.6 & 36 & 34.4 & 34.8 & 35.8 & 34.4 & 32.6 & 33.4 & 31 & 30 \\
\hline$\overline{\mathbf{X}}$ & 36.9 & 36.2 & 35.1 & 35.6 & 35.9 & 34.9 & 27.5 & 31.1 & 30.6 & 27.8 \\
\hline$\pm \mathrm{SD}$ & \pm 0.3 & \pm 0.5 & \pm 0.6 & \pm 0.9 & \pm 0.6 & \pm 0.8 & \pm 2.9 & \pm 3.8 & \pm 3.3 & \pm 2 \\
\hline$\pm \mathrm{SE}$ & \pm 0.06 & \pm 0.1 & \pm 0.1 & \pm 0.2 & \pm 0.1 & \pm 0.2 & \pm 0.7 & \pm 0.9 & \pm 0.8 & \pm 0.5 \\
\hline
\end{tabular}

during anaesthesia shivered in the recovery room. Also no patient who was warmed during operation complained of a cough, sore throat, or chest discomfort during convalescence that could be attributed directly to the inhalation of warmed anaesthetic gases.

When the temperatures of the unwarmed patients who had shivered were compared to those who had not shivered (Table IV), the only real difference was in the toe temperatures $\left(s=29.9^{\circ}\right.$ $\mathrm{C}$, n.s. $=31.2^{\circ} \mathrm{C}$ ) late in the operation. This peripheral skin temperature difference probably does not provide the stimulus for shivering.

\section{Discussion}

Skin temperature of the great toe was used to represent peripheral temperature for several reasons. Past studies have utilized toe temperatures as an index of cardiovascular status during traumatic conditions, such as burns, ${ }^{,}$frost bite, ${ }^{9}$ shock, ${ }^{10}$ and to measure cutaneous blood flow." The same method might apply to prolonged major operations. ${ }^{12}$ Temperature of the skin of the big toe is dependent almost totally upon cutaneous blood flow due to lack of adjacent tissue insulation or metabolism which might alter temperatures of skin over other areas of the body (fat insulation, muscle metabolism). In addition, the gauze pad covering the temperature probe over the big toe is easily applied and efficiently limits rapid changes due to sudden alterations in ambient conditions which could influence skin heat loss from evaporation, convection, or radiation.

A combination of things may have contributed to the hypothermia and shivering noted during this study (Figures 1 and 2). These might include loss of heat from skin of inadequately covered patients (decreased insulation), low ambient temperature in the operating room, anaesthesiarelated skin vasodilatation increasing peripheral heat loss, open abdominal incisions which increase core heat loss, and anaesthesia-induced impairment of compensatory thermogenesis.

The mechanism by which body core warming is accomplished during inhalation of warmed anaesthetic gases has not been clearly estab- 
TABLE III

Temperatures $\left({ }^{\circ} \mathrm{C}\right)$ of the 20 Warmed Patients Before Anaesthesia (PA), During Anaesthesia (A), late During Operation (LS), and Early During Recovery (ER) (Means $\pm S D, \pm S E M$ )

\begin{tabular}{|c|c|c|c|c|c|c|c|c|c|c|}
\hline \multirow[b]{2}{*}{ Pt.\# } & \multicolumn{4}{|c|}{ Tympanic } & \multicolumn{2}{|c|}{ Oesophageal } & \multicolumn{4}{|c|}{ Toe } \\
\hline & PA & $A^{*}$ & LS & ER† & A & LS & PA & $\mathbf{A}$ & LS & ER \\
\hline 1 & 37 & 36.5 & 37.7 & 37 & 36.5 & 37.4 & 32 & 32.5 & 34 & 33.9 \\
\hline 2 & 36.9 & 36 & 37 & 37.2 & 35 & 38 & 25.4 & 33 & 35.2 & 33.5 \\
\hline 3 & 36.6 & 35 & 36 & 36.4 & 35 & 36.5 & 26 & 32 & 33.1 & 30.6 \\
\hline 4 & 36.6 & 36 & 36.5 & 36.5 & 36.3 & 37.3 & 24.3 & 31.6 & 34.9 & 30 \\
\hline 5 & 36.3 & 36.3 & 36.9 & 37.2 & 38 & 37.4 & 28.1 & 27.5 & 32.9 & 33.5 \\
\hline 6 & 37.3 & 36.5 & 36.8 & 37.2 & 36 & 37 & 32.5 & 35 & 36 & 33.4 \\
\hline 7 & 37.5 & 37.1 & 37.9 & - & 36.9 & 37.8 & 29 & 30 & 32.5 & - \\
\hline 8 & 37.3 & 36.5 & 37.5 & 37.5 & 36.6 & - & 28.2 & 34.8 & 36 & 34.3 \\
\hline 9 & 37,2 & 36.3 & 37.5 & 38 & 35.9 & 37.1 & 25.9 & 33.1 & 35.6 & 29.1 \\
\hline 10 & 36.3 & 36.1 & 37.2 & 37.2 & 36.3 & 37.8 & 31.8 & 34.7 & 35.4 & 33.6 \\
\hline 11 & 36.6 & 36.1 & 37.6 & 37.4 & 36.8 & 38.2 & 28.2 & 35.2 & 36.7 & 33 \\
\hline 12 & 37.3 & 36.6 & 36.9 & 37.2 & - & 37 & 24.6 & 33.5 & 35 & 34 \\
\hline 13 & 37.3 & 36.7 & 37.3 & 37.1 & 36.6 & 38 & 26.4 & 34 & 35.8 & 34.8 \\
\hline 14 & 37.2 & 36.2 & 36.9 & 36.8 & 36.3 & 37.2 & 27.2 & 32.6 & 30 & 28.5 \\
\hline 15 & 36.9 & - & 36.2 & 36.4 & - & - & 24.2 & - & 30.2 & 30.2 \\
\hline 16 & 36.4 & 36.2 & 36.5 & 36.4 & 36.5 & 36.7 & 26.6 & 29 & 33,5 & 31.5 \\
\hline 17 & 36.9 & 35.9 & 36.8 & 37 & 36 & 37 & 26.5 & 32.9 & 35 & 32 \\
\hline 18 & 37.3 & 36.6 & 37.2 & 36.8 & 36.9 & 38.2 & 29.4 & 34.6 & 35.6 & 32.6 \\
\hline 19 & 36.6 & 36.2 & 33 & 37 & 36 & 37.8 & 27.5 & 32.9 & 32.3 & 32.5 \\
\hline 20 & 37 & 36.6 & 37.2 & 37.4 & 36.5 & 37.4 & 25.6 & 32.9 & 36 & 33.4 \\
\hline$\overline{\mathbf{X}}$ & 36.9 & 36.3 & 37 & 37 & 36.3 & 37.4 & 27.5 & 32.7 & 34.3 & 32.3 \\
\hline$\pm \mathrm{SD}$ & \pm 0.4 & \pm 0.4 & \pm 0.5 & \pm 0.4 & \pm 0.7 & \pm 0.5 & \pm 2.5 & \pm 2.0 & \pm 1.9 & \pm 1.8 \\
\hline $\pm S E$ & \pm 0.09 & \pm 0.1 & \pm 0.1 & \pm 0.1 & \pm 0.2 & \pm 0.1 & \pm 0.6 & \pm 0.5 & \pm 0.4 & \pm 0.4 \\
\hline
\end{tabular}

$A^{*}=$ Following inhalation anaesthesia for 20 minutes without surgical stimulation ERT = Thirty minutes after arriving in the recovery room.

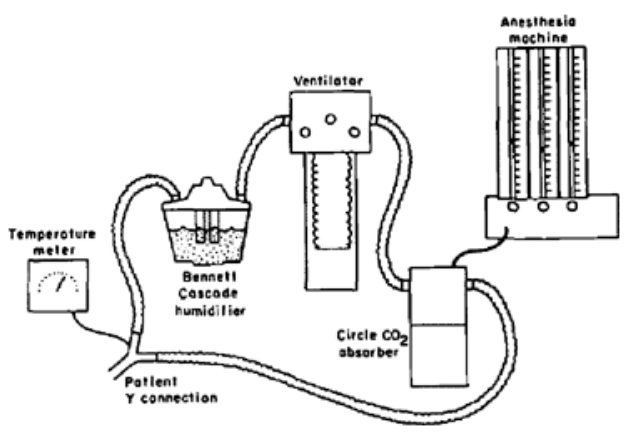

Figure 3. Modified humiditier in the anaesthesia circuit which provided warm humidified anaesthetic gases to the patients within a controlled temperature range $\left(42^{\circ} \mathrm{C}\right.$ to $\left.47^{\circ} \mathrm{C}\right)$.

lished. ${ }^{13}$ Warmed inspired gases could transfer heat by establishing heat gradients directly across tissue in the upper mediastinum (oesophagus, myocardium, superior vena cava), across bronchial mucosa to bronchial blood which drains through the azygos vein and superior vena cava back to the pulmonary vascular circulation and across alveolar membranes to pulmonary blood. Pavlin and associates (14) attempted to resolve this question by measuring the heat gradient across the pulmonary artery to the left ventricle in dogs warmed by inhalation of warmed humidified oxygen. They concluded that the major part of the heat exchanged appeared to be transferred across upper airways through the bronchial circulation.

The causes of post-anaesthesia shivering have also not been clearly defined. ${ }^{4}$ Several authors ${ }^{2,15}$ have reported a lack of correlation between hypothermia during operation and the incidence of post-anaesthesia shivering. However, shivering is usually considered to be a means of rapid acute thermogenesis in man. ${ }^{16}$ If our shivering patients were not in need of acute thermogenesis because they were not hypothermic, the question then is: why were they shivering? Unfortunately we do not have measurements of the hypothalamic temperature "setpoint" of our postanaesthetic patients to compare them with core temperatures.

Patients who did shiver may have needed acute shivering thermogenesis in response to the dif- 
TABLE IV

Temperatures $\left({ }^{\circ} \mathrm{C}\right.$ ) Compared Between Unwarmed Patients Who Shivered (s) and Did Nor Shiver (ns) (MEANS $\pm \mathrm{SD}, \pm \mathrm{SEM}$ )

\begin{tabular}{|c|c|c|c|c|c|c|c|c|c|c|}
\hline \multirow[b]{3}{*}{ Pt.\# } & \multicolumn{6}{|c|}{ Late During Operation } & \multicolumn{4}{|c|}{ Early Recovery } \\
\hline & \multicolumn{2}{|c|}{ Tympanic } & \multicolumn{2}{|c|}{ Oesophageal } & \multicolumn{2}{|c|}{ Toe } & \multicolumn{2}{|c|}{ Tympanic } & \multicolumn{2}{|c|}{ Toe } \\
\hline & $\mathbf{s}$ & ns & $\mathbf{s}$ & ns & s & ns & $\mathbf{s}$ & ns & s & ns \\
\hline $\begin{array}{l}\frac{n}{x} \\
\pm S D \\
\pm S E \\
p<\end{array}$ & $\begin{array}{l}10 \\
35.1 \\
\pm 0.7 \\
\pm 0.2 \\
\text { NS }\end{array}$ & $\begin{array}{c}10 \\
35.1 \\
\pm 0.6 \\
\pm 0.2\end{array}$ & $\begin{array}{l}10 \\
34.8 \\
\pm 0.8 \\
\pm 0.3 \\
\text { NS }\end{array}$ & $\begin{array}{l}10 \\
35.1 \\
\pm 0.9 \\
\pm 0.3\end{array}$ & $\begin{array}{c}10 \\
29.9 \\
\pm 3.1 \\
\pm 1.0 \\
\text { NS }\end{array}$ & $\begin{array}{l}10 \\
31.2 \\
\pm 3.6 \\
\pm 1.2\end{array}$ & $\begin{array}{c}10 \\
35.8 \\
\pm 0.9 \\
\pm 0.3 \\
\text { NS }\end{array}$ & $\begin{array}{c}9 \\
35.3 \\
\pm 0.8 \\
\pm 0.3\end{array}$ & $\begin{array}{l}10 \\
27.9 \\
\pm 1.7 \\
\pm 0.6 \\
\text { NS }\end{array}$ & $\begin{array}{r}9 \\
27.6 \\
\pm 2.5 \\
\pm 0.9\end{array}$ \\
\hline
\end{tabular}

TABLE $\mathrm{V}$

Mean Temperatures $\left({ }^{\circ} \mathrm{C}\right.$ ) Compared Between 20 Warmed (w) and 20 Unwarmed (Uw) Patients at Various Times During Operation and Recovery

\begin{tabular}{|c|c|c|c|c|c|c|c|}
\hline \multirow[b]{2}{*}{ Event } & \multirow[b]{2}{*}{ Time } & \multicolumn{2}{|c|}{ Tympanic } & \multicolumn{2}{|c|}{ Oesophageal } & \multicolumn{2}{|c|}{ Toe } \\
\hline & & uw & $\mathbf{w}$ & uw & $w$ & uw & $w$ \\
\hline Pre-Anaesthesia & & 36.9 & 36.9 & & & 27.5 & 27.5 \\
\hline Anaesthesia & $20 \mathrm{~min}$ & 36.2 & 36.3 & 35.9 & 36.3 & 31.1 & 32.7 \\
\hline Operation & 1 hour & 35.2 & $36.4^{*}$ & 34.9 & $36.9^{*}$ & 32.4 & 34.0 \\
\hline Operation & Completed & 35.1 & $37.0^{*}$ & 34.9 & $37.4^{*}$ & 30.6 & $34.3^{*}$ \\
\hline Recovery & $30 \mathrm{~min}$ & 35.6 & $37.0^{*}$ & & & 27.8 & $32.3^{*}$ \\
\hline Recovery & 2 hours & 36.7 & 37.3 & & & 28.0 & 30.7 \\
\hline
\end{tabular}

$* p<0.001$.

ference between their "setpoint" and the core temperature. Patients with a lesser difference between "setpoint" and core temperature may have slowly rewarmed themselves without shivering by conserving heat by the mechanism of peripheral vasoconstriction.

Non-shivering thermogenesis may also play a role in the rewarming of hypothermic patients. Leg limb flow occlusive venous plethysmog. raphy measurements carried out as a parallel investigation on some of these same patients showed shivering-like muscle movements demonstrated by a mercury strain gauge and electronic recorder, which were not detectable by either sight or feel by the patient or the observer. This sub-clinical shivering may account for the rapid rewarming of some of our patients who were not warmed during operation and did not shiver after anaesthesia.

From the evidence presented in this paper we conclude that pulmonary ventilation with warm humidified anaesthetic gases provides heat transfer by the lungs and so prevents hypothermia during operation and post-anaesthesia shivering is prevented by maintaining the patient normothermic in both the operating room and in the recovery room.

\section{SUMMARY}

This study involves ventilation of the lungs with warmed humidified anaesthetic gases during prolonged elective abdominal operations. Tympanic, oesophageal and toe temperatures were compared between twenty warmed and twenty un-warmed patients at various times during operation and recovery. Fifty per cent (10/20) unwarmed patients shivered in the recovery room, while none of the warmed patients shivered. Our data indicate that pulmonary ventilation with warm humidified anaesthetic gases provides heat transfer by the lungs, preventing hypothermia during operation and post-anaesthesia shivering is prevented by maintaining the patient normothermic in both the operating room and the recovery room. 


\section{RéSUMÉ}

Au cours d'interventions abdominales électives de longue durée, nous avons utilisé des gaz anesthésiques humidifiés et réchauffés pour ventiler 20 de nos malades. Nous avons comparé les températures tympaniques, oesophagiennes et cutanées (gros orteil) de ces 20 malades à celles de 20 malades subissant des interventions du même genre et ventilés avec des gaz anesthésiques non chauffés. Cinquante pour cent (10/20) des malades non réchauffés par des gaz ont présenté du tremblement dans la salle de réveil. Aucun des malades ayant reçu des gaz chauds n'a tremblé.

Nos résultats indiquent qu'une ventilation pulmonaire utilisant des gaz anesthésiques chauds et humidifiés permet un transfert de température au niveau du poumon et prévient l'hypothermie en cours de chirurgie, et que le tremblement post-opératoire est évité par le maintien du malade en normothermie.

\section{ACKNOWLEDGEMENTS}

The authors wish to thank Ms. Kathleen Lewis, Ms. Willie Tanner, and Ms. Irene Cressey for their skillful technical assistance and Ms. Ruth Claus for her editing and typing. This study was supported in part by Grant RR-133 from the General Clinical Research Center of the Division of Research Resources, National Institute of Health, and by a grant from the Parker B. Francis Foundation, Kansas City, Missouri.

\section{REFERENCES}

1. Soliman, M.G. and Gillies, D.M.M. Muscular hyperactivity after general anaesthesia. Canad. Anaesth. Soc. J. 19: $\$ 29$ (1972).

2. COHEN, M. An investigation into shivering follow- ing anaesthesia-a preliminary report. Proc. Roy. Soc. Med. 60: 752 (1967).

3. Bay, J., NunN, J.F., and Prys-Roberts, C. Factors influencing arterial $\mathrm{PO}_{2}$ during recovery from anaesthesia. Brit. J. Anaesth. 40: 398 (1968).

4. Artusio, J.F. Clinical Anesthesia, Ist ed., Philadelphia: F.A. Davis Co., Prys-Roberts, C., Postanesthesia shivering, Vol. 3, Chapter 24: 358 (1968).

5. Morris, R.H., Kumar, A. The effect of warming blankets on maintenance of body temperature of the anesthetized paralyzed adult patient. Anesthesiology 36: 408 (1972).

6. Kugelbero, J., Schuller, H., Berg, B. Treatment of accidental hypothermia. Scand. J. Thorac. Cardiovasc. Surg. 1 : 142 (1967).

7. CRINO, M.H., NAGEL, E.L. Thermal burns caused by warming blankets in the operating room. Anesthesiology 29: 149 (1968).

8. Comroe, J.H. Physiology of respiration, ist ed, Chicago: Year Book Medical Publishers (1966) p. 15.

9. BuWALDA, G. Thermographic assessment of burns and frostbite. Bibl. Radiol. 5: 178 (1969).

10. JOLY, H.R., WEIL, M.H. Temperature of the great toe as an indication of the severity of shock. Circulation 39: 131 (1969).

11. Burton, A.C. The range and variability of the blood flow in the human fingers and the vasomotor regulation of the body temperature. Am. J. Physiol. 127: 437 (1939).

12. Egerhart, R.C. and Trezek, G.J. Central and peripheral rewarming patterns in postoperative cardiac patients. Critical Care Med. 1: 239 (1973).

13. Tausk, H.C., Miller, R., and Roberts, R. Maintenance of body temperature by heated humidification. Anesth. \& Analg. 55: 719 (1976).

14. Pavlin, E., Hornbein, T.E., and Chaney, R. Rewarming of hypothermic dogs with use of heated nebulized ventilation. Abstracts of Scientific Papers, Am. Soc. of Anesth., 1976 Annual Meeting, p. 105.

15. MolR, D.D., and DoYle, P.M. Halothane and postoperative shivering. Anesth. \& Analg. 42: 423 (1963).

16. BrengelmanN, G. Physiology \& Biophysics, Ruch-Patton, 20th ed., Philadelphia: Saunders, Vol. III, p. 123 (1973). 